\title{
A CONTRIBUTION TO THE LINGUISTIC HISTORY OF THE LÍNGUA GERAL AMAZÔNICA
}

\author{
Aryon Dall'Igna RODRIGUES* \\ Ana Suelly Arruda Câmara CABRAL ${ }^{* *}$
}

- ABSTRACT:This paper demonstrates that the changes undergone by Língua Geral Amazônica over 300 years, although it had been exposed to external interference from the Portuguese language and a number of indigenous languages, its development has been gradual without a breakdown on its transmission. This accounts for its genetic origin, according to the principles underlying the Comparative Method and the theoretical model proposed by Thomason and Kaufman (1988). This approach brings evidence against the claim that Língua Geral Geral Amazônica is a creole language neither a language developed by the seventeenth century Jesuit missionaries. Therefore, this paper contributes to the viewing of Língua Geral Amazônica is a version of the Tupinambá language which developed outside the Tupinambá villages but maintaining its genetic relations with the subbranch III of the Tupí-Guaraní linguistic family, together with Tupinambá, Tupí Antigo and the Língua Geral Paulista, as proposed by Rodrigues (1985), in his internal classification of that family.

- KEYWORDS: Língua Geral Amazônica. Historical changes. Normal transmission. External interferences. Tupí-Guaraní family.

\section{Introduction $^{1}$}

The Amazonian Língua Geral (LGA) compared to Tupinambá, of which it is the only surviving variety, reveals itself very simplified in all of its dialects recorded since the 18th century, with respect to its phonology and morphosyntax. This simplification, added to lexical and syntactic borrowings from Portuguese, has induced several scholars to consider it a language of non-genetic origin, either artificially created by the Jesuits on the basis of Tupinambá, or a result of a mixture of Portuguese and Tupinambá, or yet of imperfect learning of Tupinambá by speakers of Portuguese and other genetically distinct languages. However, if we consider linguistic data corresponding to different moments of the history of LGA, we observe that the reductions of the Tupinambá linguistic subsystems in

* UNB - Universidade de Brasília. Departamento de Lingüística. Brasilia - D.F. - Brasil. 70910-900 - aryon@unb.br

** UNB - Universidade de Brasília. Departamento de Lingüística. Brasília - D.F. - Brasil. 70910-900 - asacc@unb.br

1 We are thankful for important comments from two anonymous referees who collaborated to improve the content of the present paper. 
LGA did not occur suddenly, but in different proportions in the areas where this language was spoken during the last four hundred years. The present paper focus on some important morphosyntactic changes underwent by LGA throughout its history, taking into account a relevant amount of data, which provide evidence against the view that the origin of LGA was non-genetic. It also seeks to contribute to understanding the role of the Jesuit missionaries in the consolidation of LGA in their missions and its expansion during the colonial period.

\section{The later $17^{\text {th }}$ century and $18^{\text {th }}$ century LGA}

We have examined four of the published documents of 18th century LGA: Doutrina Cristã em Língua Geral dos Indios do Estado do Brasil e Maranhão, composta pelo P. Philippe Bettendorf, traduzida em língua irregular, e vulgar uzada nestes tempos (DOUTRINA..., 16--)², Dicionário Português-Brasiliano (ONOFRE, 1934), Caderno da Língua (CL) (CADERNO..., 1937), and Vocabulário PortuguêsBrasílico (VPB) (VOCABULÁRIO..., 1951). These documents, that correspond approximately to the phase called Brasiliano by F. Edelweiss (1969), reveal varieties already differentiated from the Tupinambá described by Anchieta (1933), and Figueira (1878), and present in Antonio de Araujo's catechism (1618), and in the second editions of both by J. F. Bettendorf with a revision by Bertolameu de Leão (1687 and 1686, respectively), as well as in the catechism written by Bettendorf (1687) himself in the $17^{\text {th }}$ century. Some of the differences between the written data of $18^{\text {th }}$ century LGA and the language attested in the sources mentioned consist in the replacement of some original Tupinambá morphological devices by syntactic ones and in some light reductions in its morphological systems relational, casual, personal, modal, and of voice. These changes, as attested in the $18^{\text {th }}$ century documents, are indications of the nature and directions of the main posterior changes that came to be established in LGA, when the Jesuit missionaries no more acted in the villages of Amazonia (their expulsion from Brazil was in 1759).

The data examined here ${ }^{3}$ also highlight important indications that, after approximately one hundred years of use out of its natural social context - the

\footnotetext{
Differently from F. Edelweiss (1969, p.138) we consider this manuscript a work by Bettendorf' copied by another missionary some years after the publication of that work. In favor of our interpretation speak not only the expression "translated into the irregular and vulgar language used in these times", but also the information by the historian of the Jesuits in Brazil, F. Serafim Leite, who states that the letter of this manuscript reveals a foreign (i. e. non-Portuguese) writer, but is not that of Bettendorf. Indeed, the language of this manuscript reveals a light differentiation from the Tupinambá as documented previously, and that it probably represents the LGA spoken at the end of the $16^{\text {th }}$ century and beginning of 17 th. However, we will consider it provisorialsly an undate anonymos work.

3 Abbreviations: $\mathrm{ARG}=$ argument; CAUS $=$ causative; $\mathrm{C} . \mathrm{COM}=$ commitative causative; $\mathrm{DAT}=$ dative; DOUBT $=$ dubitative aletic particle; $\mathrm{GER}=$ gerund; $\mathrm{IND} . \mathrm{II}=$ indicative II mood; $\mathrm{NOM}=$ nominalizer; $\mathrm{Q}=$ question; $\mathrm{R}^{1}=$ relational prefix
} 
Tupinambá villages - LGA, although presenting various signs of structural changes in process, was still conserving strong characteristics of the Tupinambá original inflexional morphology. The results of the contrastive analysis developed here favor the vision that LGA is not a language whose origin is non-genetic. Instead, they constitute indications that LGA is a modified version of the Tupinambá language, which has undergone gradual changes since the time it came to be used as the first language of children born in the mestizo social contexts developed during the first decades of Portuguese colonization in Maranhão and Grão Pará (RODRIGUES, 1996).

\section{Stem classes}

The first set of grammatical features considered here is the system of relational prefixes present in Tupinambá, which constitute one of the most intricate inflectional devices of the Tupí-Guaraní grammar. The relational prefixes have been so called by Rodrigues since his early studies on the Tupinambá language (RODRIGUES, 1952, 1953), because their fundamental function is to relate a dependent stem - noun, postposition or verb - to its determiner, enabling it to occur in the syntax. The relational prefixes are also among the grammatical marks that have shown strong resistance in the history of any individual Tupí-Guaraní language.

Rodrigues (2000) has identified four relational prefixes in Tupinambá, represented here by $R^{1}, R^{2}, R^{3}$, and $R^{4}$. $R^{1}$ prefix, which has two allomorphs $r$-and $\emptyset$-, signals that the dependent theme forms a syntactic constituent with its determiner, which is the immediate preceding expression. $\mathrm{R}^{2}$ prefix, whose allomorphs are $S^{-} \sim j O S-\infty t-\infty i^{-} \sim j O-\infty \emptyset$-, signals that the dependent stem and its determiner are not contiguous, the latter being expressed elsewhere or going unexpressed. $\mathrm{R}^{3}$ prefix signals that the determiner is generic and human and its allomorphs are $t-\infty m-\infty$ ?- $\infty \mathrm{V}-\rightarrow \emptyset$. Finally, $\mathrm{R}^{4}$ prefix $o^{-}\left(o^{-} \sim W^{-}\right)$relates the dependent stem to its determiner, signing that it is co-referent to the subject of the main clause. Rodrigues (1981) has proposed the division of the Tupinambá relative stems into three main classes. Those combining with the allomorph $\emptyset$ - of $\mathrm{R}^{1}$ prefix were included into Class I, those combining with the allomorph $r$ - of this same prefix were included into Class II, and those stems which do not combine with any relational prefix, into Class III. Each of the two first stem classes was divided into subclasses according to the allomorphs of the $\mathrm{R}^{2}$ and $\mathrm{R}^{3}$ prefixes. The following charter adapted from Rodrigues (1981) shows the organization of such a division:

marking the contiguity of a determiner; $\mathrm{R}^{2}=$ relational prefix marking the non-contiguity of a determiner; $\mathrm{R}^{3}=$ relational prefix marking a co-reference whit the subject of an intransitive verb; $\mathrm{R}^{4}=$ relational prefix marking a generic determiner; $\mathrm{LP}=$ punctual locative; $\mathrm{NEG}=$ negation; $\mathrm{OPT}=$ optative; $\mathrm{REC}=$ reciprocal; $\mathrm{REF}=$ reflexive; $\mathrm{REL}$ = relational; SUB = subjunctive. 


\begin{tabular}{|l|l|l|l|l|l|l|l|}
\hline & \multicolumn{4}{l|}{ Class I } & \multicolumn{2}{l|}{ Class II } & Class III \\
\hline & Ia & Ib & IIa & IIb & IIc & Iid & \\
\hline $\mathrm{R}^{1}$ & $\emptyset-$ & $\emptyset-$ & $r-$ & $r-$ & $r-$ & $r-$ & -- \\
\hline $\mathrm{R}^{2}$ & $i-\sim j o-$ & $i-$ & $s-\sim j o s-$ & $t-$ & $s-$ & $s-$ & -- \\
\hline $\mathrm{R}^{3}$ & $\emptyset-$ & $m-$ & $t-$ & $t-$ & $\emptyset-$ & $V-\rightarrow \emptyset$ & -- \\
\hline $\mathrm{R}^{4}$ & $o-$ & $o-$ & $o-$ & $o-$ & $o-$ & $o-$ & -- \\
\hline
\end{tabular}

Chart 1 - Tupinambá relational prefixes

Source: Author himself.

\section{Relational prefixes in nouns}

$18^{\text {th }}$ century LGA conserved systematically the relational prefixes $R^{1}, R^{2}$ and $R^{3}$ in nouns, although $\mathrm{R}^{4}$ prefix was unsystematically replaced by $\mathrm{R}^{2}$ prefix (example 8), in situations that originally required the former(as in 9):4

Class Ia

$\mathrm{R}^{1}$

1)

Tupã nhëénga rupí

Tupã Ø-je'én-a r-upí

GOD $\mathrm{R}^{1}$-speak -ARG $\mathrm{R}^{1}$-by.means.OF

‘..by means of God's speech' (DOUTRINA..., [16 - ]p. 5v).

$\mathrm{R}^{2}$

2)

Marátäé tipé inhëénga poracaraçába reraçóu?

marã ta'é tipé i-je'én-a Ø-porakara-sáß-a r-era-só-w?

how $\mathrm{Q}$ DOUBT $\mathrm{R}^{2}$-speak-ARG $\mathrm{R}^{1}$-accomplish-NOM-ARG $\mathrm{R}^{1}$-C.COM-go-IND.II 'how to accomplish his words?' (DOUTRINA..., [16 - ], p. 27).

$\mathrm{R}^{3}$

3)

opacatú nhëenga cuapára

opá-katú Ø-je'én-a

all-well $\quad \mathrm{R}^{3}$-speak-ARG $\quad \mathrm{R}^{1}$-know-NOM-ARG

'one who knows all languages...' (DOUTRINA..., [16 - ], p.45v).

Edelweiss (1969, p.141) offers an additional example from DCLG, which shows the replacement of $\mathrm{R}^{4}$ by $\mathrm{R}^{2}$. 
4)

onhëénga pupé nhóte
o-je'én-a
$\mathrm{R}^{4}$-speak-ARG
Ø-pupé
poupe jote
'... only with his (own) words' (DOUTRINA..., [16 - ], p.11).

Class IIb

$\mathrm{R}^{1}$

5)

oré rúba

oré $\quad \boldsymbol{r}$-ú $\beta-a$

WE.EXCL. $\quad \mathrm{R}^{1}$-father-arg

'our father' (DOUTRINA..., [16 - ], p. 77).

$\mathrm{R}^{2}$

6)

\section{túba}

$\boldsymbol{t}-\dot{u} \beta-a$

$\mathrm{R}^{2}$-father-arg

'his father' (DOUTRINA..., [16 - ], p.77).

$\mathrm{R}^{3}$

7)

Tupã Túba

Tuрã $\boldsymbol{t}$-ú $\beta-a$

god $\mathrm{R}^{3}$-father-ARG

'God father' (DOUTRINA..., [16 - ], p.9).

8)

omomytá cerá erimbäé ojoecé ipý ipó ipyá cutucagöera

o-mo-mitá será erima’é o-jo-esé

3-CAUS-remain DOUBT once $\mathrm{R}^{3}$-REC-in.relation.to

$i-p \dot{+} \emptyset \quad i-p o ́-\emptyset \quad i-p \ddot{z} \ddot{a}-\emptyset \quad \emptyset$-kutúk-á-wér-a

$\mathrm{R}^{2}$-foot-ARG $\mathrm{R}^{2}$-hand-ARG $\quad \mathrm{R}^{2}$-entrails-ARG $\mathrm{r}^{1}$-pierce-NOM-RET-ARG 'did he make remain with himself his feet, hands and entrails wound marks?' (DOUTRINA..., [16 - ], p.30). 
The presence of the postposition o-jo-esé 'with himself' in the example above indicates that the possessor of -pý, -pó and -py'áis co-referential with the subject of the verb -momytá. In this case, these nouns should receive the co-referential o- (R4) (as in 9), not the non co-referential i- (R2) (example 8).

9)

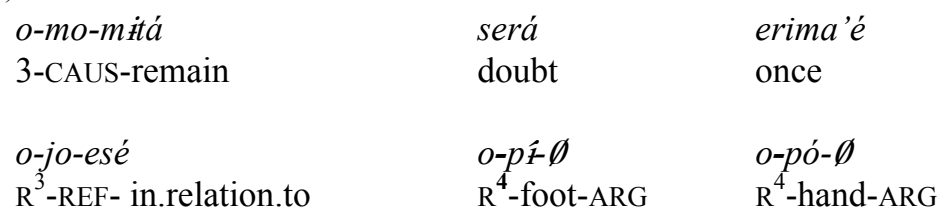

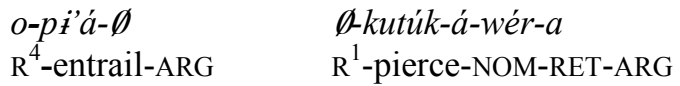

'did he make remain with himself his own feet, hands and entrails wound marks?'

Data like 8 show that in the 18th century the relational prefix R4 started loosing its functionality, a process that was accomplished in the $19^{\text {th }}$ century, as seen in the examples below from the dialect spoken on the Rio Negro:

10)

Çuaçú oikuénte oruíari rẹcệ cẹ tịmãn rẹcệ suasú o-ikuénte o-ruiári r-esé s-etimã r-esé 3-calm 3-trust $\mathrm{R}^{1}$-for $\mathrm{R}^{2}$-leg $\mathrm{R}^{1}$-for

'The deer was calm for he was confident of his own legs' (MAGALHÃES, 1876, I, p.88).

11)

Cunhã-mucú, çóca upé, onhehẽ i mệna çupé:

kuñãmukú s-óka upé o-ñe?ẽ i-ména supé

young.girl $\mathrm{R}^{2}$-house at 3-speak $\mathrm{R}^{2}$-husband to

'At home the young girl said to her husband...' (MAGALHÃES, 1876, I, p.168).

By the $19^{\text {th }}$ century, the original relational system of Tupinambá was already reduced in LGA to two morphemes, R1- and R2-, as illustrated by examples 12 (from the Negro River) and 13 (from the Juruá River): 
12)

$\begin{array}{lllllll}\text { pirakaçára } & \text { oieréo } & \text { i igára } & \text { irúmo } & \text { ipéca } & \text { arãma } & \text { i akãnga } \\ \text { pirakasára } & \text { o-jeréw } & \text { i-igára } & \text { irúmo } & \text { ipéka } & \text { arama } & \text { i-akánga } \\ \text { FISHER } & \text { 3-CHANGE } & \mathrm{R}^{2} \text {-CANOE } & \text { WITH } & \text { DUCK } & \text { INTO } & \mathrm{R}^{2} \text {-HEAD }\end{array}$

FISHER 3-CHANGE $\mathrm{R}^{2}$-CANOE WITH DUCK INTO $\mathrm{R}^{2}$-HEAD
ipéca- akãnga arãma
ipéka-akálgga aráma
DUCK-HEAD INTO

'The fisher changed with his canoe into a duck, his head into a duck's head' (MAGALHÃES, 1876, I, p.168).

13)

$\begin{array}{lllllc}\text { Çuaçú } & \text { oikuénte } & \text { oruiári } & \text { rẹcẹ́ } & \text { cẹ tịmãn } & \text { recé } \\ \text { suasú } & \text { o-ikuẽte } & \text { o-rujári } & \text { r-esé } & \text { s-etimã } & \text { resé } \\ \text { DEER } & \text { 3-BE.CALM } & \text { 3-TRUST } & \mathrm{R}^{1} \text {-IN } & \mathrm{R}^{2} \text {-LEG } & \mathrm{R}^{1} \text {-IN }\end{array}$

'The deer was calm because he trusted his legs' (MAGALHÃES, 1876, I, p.212).

It is important to observe that the same kind of reduction also took place in the individual history of other Tupí-Guaraní languages, such as Urubú-Ka'apór and Guajá. Although this change may have occurred in these languages under the influence of LGA, the reduction underwent by LGA itself was not the result of missionary interference, as shown by the inspection of linguistic material produced by the Jesuits in the $16^{\text {th }}$ and $17^{\text {th }}$ centuries. ${ }^{5}$ Further examples of relational prefixes in verbs and postpositions will be given in the following sections, when other aspects of the LGA will be considered.

\section{The case system}

Rodrigues $(1981,2000)$ has described six morphological cases for Tupinambá: four locative cases - punctual, diffuse, situational and translative -, one dative case (exclusively in independent pronouns), and one argumentive case. This latter inflects nominal and verbal roots or stems allowing them to have a syntactic argument function:

Some Tupí-Guaraní languages also have reduced the number of allomorphs of the $\mathrm{R}^{3}$ relational prefix or have changed the morphological class of certain lexical items (CABRAL, 2001). 
Locative

$$
\text { after } \mathrm{V} \quad \text { after } \mathrm{V}^{\mathrm{n}} \quad \text { after } \mathrm{C} \quad \text { after } \mathrm{N}
$$

$\begin{array}{lllll}\text { Punctual } & -p e & -m e & -i p e & -i m e \\ \text { Diffuse } & -\beta o & -\beta o & -i \beta o & -i \beta o \\ \text { Situational } & -j & -j & -i & -i \\ \text { Translative } & - \text { ramo } & - \text {-namo } & - \text { amo } & - \text { amo } \\ \text { Dative } & -\beta e \sim-\beta o & -m e \sim-m o & - & - \\ \text { Argumentive } & -\emptyset & -\emptyset & -a & -a \text { (RODRIGUES, 1994). }\end{array}$

LGA in the 18th century preserved intact the punctual locative (14-15) and the dative (16):

14)

Coýr ybýpe peicó nitío ybypóramo

koýr ißß́-pe pe-ikó nitíw ißß́-pór-amo

now earth-PL 23-be NEG earth-inhabitant-TRANS

'you are now on the earth (but) not as its (permanent) inhabitants'

(DOUTRINA..., [16 - ], p.2).

15)

perapé cycába ybakype cecóu

pé r-apé Ø-sík-á $\beta$-a ißák-ipe s-ekó-w

$23 \mathrm{R}^{1}$-path-ARG $\mathrm{R}^{1}$-arrive-NOM-ARG heaven-PL $\mathrm{R}^{2}$-be-IND.II

'the arrival of your path is in the heaven' (DOUTRINA..., [16 - ], p.2).

16)

Mbäéráma recé Tupã imëéng jandébo?

\begin{tabular}{|c|c|c|c|}
\hline $\begin{array}{l}\text { ma'é-rám-a } \\
\text { thing-FUT-ARG }\end{array}$ & $\begin{array}{l}r \text {-esé } \\
\mathrm{R}^{1} \text {-in.relation.to }\end{array}$ & $\begin{array}{l}\text { tupã- } \emptyset \\
\text { god-ARG }\end{array}$ & $\begin{array}{l}i \text {-me'én } \\
\mathrm{R}^{2} \text {-give }\end{array}$ \\
\hline
\end{tabular}

'for what did God give it to us?' (DOUTRINA..., [16 - ], p.102).

Some varieties of LGA attested during the $19^{\text {th }}$ century were still preserving those two cases, as for example the variety spoken in Santarém:

17)

\begin{tabular}{|c|c|c|c|c|}
\hline $\begin{array}{l}\text { ñúnté } \\
\tilde{n} \tilde{u}\end{array}$ & té & $\begin{array}{l}\text { kuri } \\
\text { kuri }\end{array}$ & $\begin{array}{l}\text { xasó } \\
\int a-s o ́\end{array}$ & $\begin{array}{l}\text { kaápe. } \\
\text { ka'á-pe }\end{array}$ \\
\hline only & realy & FUT & 1-go & forest-LOC \\
\hline
\end{tabular}


18)

emukytan se renimú ixéu

e-mukitã sé r-enimú ifé-w

2-tie $1 \quad \mathrm{R}^{1}$-string $\quad 1$-DAT

'tie my string down for me!' (HARTT, 1938, p.333).

19)

maá taá rerúr yanéu

maá taá re-rúr jané-w

what Q 2-bring 1pl-DAT

'what did you bring to us?' (HARTT, 1938, p.337).

In this variety of LGA as well as in that of Rio Negro the punctual locative suffix also had become a new postposition opé or upé:

20)

xasó rañé amú óka opé

fa-só rañ̃e amũ óka Ø-opé

1-go IMPERF other house $\mathrm{R}^{1}$-to

'let me go to another house!' (HARTT, 1938, p.365).

In one of the varieties of the LGA spoken in the lower Rio Negro, the dative case was replaced by the particle aráma, as illustrated by the example below:

21)

xa uácẽmo ndé; xá mehẽ curí indé arãma

fa-wasémo ndé fa-me?ẽ kurí indé aráma

1-find 2 1-give FUT 2 to

'I will find you and I will give it to you' (MAGALHÃES, 1876, I, p.177).

22)

Iautí onhehẽ: - Xa putári: rẹmunúca iépe

jautí o-je?ẽ fa-putári re-munúka jepé

tortoise 3-speak 1-want 2-cut one

çuaxára inẹ arãma; amũ, ixé arãma.

suafára iné aráma amũ ifé aráma.

portion 2 to other 1 to

'the tortoise said: I want to separate a portion for you and another one for me’ (MAGALHÃES, 1876, I, p.184). 
In other varieties of the LGA, such as the one spoken at the Juruá River, the locative case came to be manifested after nouns exclusively by the postposition opé:

23)

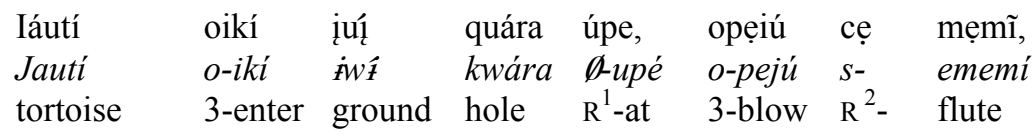

opuraçạain oikọ́: fin, fin, fin, ...

(opuraçaĩ)

o-purasãj

o-ikó fin, fin, fin

3-to.dance 3-be fin, fin, fin

'the tortoise entered the land hole, blew up its flute and was dancing: fin fin fin ...' (MAGALHÃES 1876, I, p.204).

As to the translative case, it was still functional in 18th century LGA (24 and 26), but was already superimposed to the argumentive form (as in 25) and replaced by the particle ráma as shown in 27-29:

Coýr ybýpe peicó nitío ybypóramo

Koýr ißß́-pe pe-ikó nitíw íßł́-pór-amo now earth-LOC 23-to.be NEG arth-inhabitant-TRANS

'now you are in the earth not as its (permanent) inhabitants' (DOUTRINA..., [16 - ], p.2).

25)

mbae rece Tupã Täýra jandé jabé apyabáramo onhemonháng

$\begin{array}{lllll}\text { ma'é } & r \text {-esé } & \text { Tupã- } \emptyset & t \text { - } a^{\prime} y \text { ý- } a & \text { jandé } \\ \text { thing } & \mathrm{R}^{1} \text {-in.relation.to } & \text { god-ARG } & \mathrm{R}^{4} \text {-son-ARG } & 12(3)\end{array}$

jaßé apyaßá-ramo o-je-moján

like man-ARG-TRANS 3-REF-make

'why God's Son made himself a human being like us? (DOUTRINA..., [16 - ], p.22v).

26)

Abá irúnamo túri?

aßá Øl-irúnamo t-úr-i

person $\mathrm{R}^{1}$-companion-TRANS $\mathrm{R}^{2}$-to.come

'he came as companion of whom?' (DOUTRINA..., [16 - ], p.24v). 
27)

Aba pe erimbäé Tupána omonháng ypý ybypóra ráma?

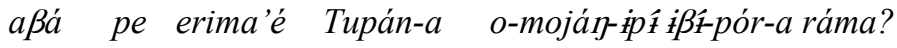

who $Q$ once god-ARG 3-make-begining-earth-inhabitant-ARG as

'who did God make once as the first earth's inhabitants?'

(DOUTRINA..., [16 - ], p.15v).

29)

Mbäé täé oimonháng ceteráma?

ma'é ta'é o-i-moján s-eté ráma

what doubt $3-\mathrm{R}^{2}$-to.make $\mathrm{R}^{2}$-body as

'what has he made as his body?' (DOUTRINA,..., [16 - ], p.14v).

Finally, with regard to the argumentative case -a, this was still functional in all nouns ending in a consonant, including borrowings from Portuguese:

30)

Tupana papéra äé eté ocuatiár

tupán-a Ø-papér-a a'é eté o-k'atiár

god-ARG $\mathrm{R}^{1}$-paper-ARG this genuine 3-draw

'he really wrote the book of God' (DOUTRINA..., [16 - ], p.48).

The grammar of 18th century LGA was still distinguishing nouns functioning as argument from nouns functioning as predicates by means of the argumentive case, as it can be illustrated by the contrastive pair t-orýb 'is happy' and oré r-orýb-a 'our happiness' (DOUTRINA..., [1-- ], p.121v). ${ }^{6}$

With respect to the diffuse and situational locatives, only examples of the former are found in the data available in 18th century LGA: "ary-bo 'on' " and "kupé-bo 'behind' " (VOCABULÁRIO..., 1951, p.50). These two cases disappeared from the $19^{\text {th }}$ century LGA.

The reduction of the Tupí-Guaraní morphological case system occurred also in other languages of the family, such as Urubú-Ka'apór, Wayampí, Emérillon (branch VIII of the family), Araweté and Anambé (branch V), Mbyá and Xetá (branch I), among others.

However, some morphemes which had the grammatical status of suffixes in Tupinambá started functioning as independent words, preserving an unstressed final $\mathbf{a}$ in the phonological form of the preceding noun, but already no more analyzable. 


\section{Verb inflectional morphology}

Tupinambá verbs combined with the following inflectional morphemes: (a) personal prefixes; b) relational prefixes; c) modal suffixes; d) voice prefixes reciprocal and reflexive; and f) a negation suffix.

\section{Indicative mood}

According to Rodrigues (1953), the Tupinambá language distinguished morphologically two varieties of the indicative mood: indicative I and indicative II. Indicative II was triggered when an adverbial expression was preceding the predicate, and indicative I occurred elsewhere, inclusive when an adverbial expression, if present in the sentence, followed the predicate. In indicative I verbs inflected for subject (prefixes a- '1', ere- '2', ja- '12(3)', oro- '13', pe- '23' e o- '3') (a-sém /1-leave/ 'I left'). In transitive verbs these person markers occurred only when the object was a third person. In this case, the verb also combined with the relational prefix R2 (a-i-nupã /1-R2-beat/ 'I beat it').

As observed by Edelweiss (1969, p.139), the 18th century LGA already presented an oscillation in the use of $\mathrm{R} 2$ with transitive verbs (examples 20-21):

Mbäétäé oimonháng ceteráma?

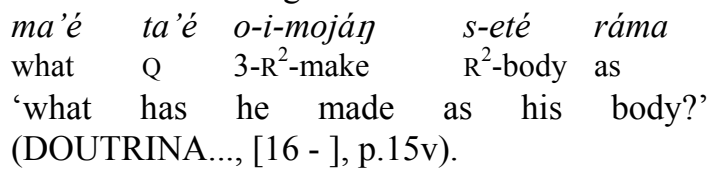

32)

Abápe erimbäé Tupána omonháng ypý ybýpóra ráma

$\begin{array}{lllll}a \beta a ́-\varnothing & \text { pe } & \text { erima'é } & \text { Tupán-a } & \text { o-moját } \\ \text { who-ARG } & \mathrm{Q} & \text { distant.PAST } & \text { god-ARG } & \text { 3-make }\end{array}$

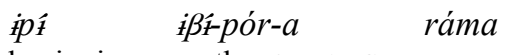

beginning earth-NOM-ARG as

'who did God make as the first earth's inhabitants?' (DOUTRINA..., [16 - ], p.15v).

Another relevant fact which is observable in the 18th century variety of the LGA recorded in the DPB is the alternation of the original first person subject awith the innovative form $\int a$-. This is a fundamental indication that the definitive substitution of the former by the latter in various dialects of LGA attested in the 
$19^{\text {th }}$ century was processual. A recurrent example of Ja- found in found is: Nitío xacoáub (NEG 1-know/can) "I do not know" or "I cannot" (ONOFRE, 1934, p.99). The data reccorded by Hartt from the $19^{\text {th }}$ century LGA dialects spoken at Ereré and among the Mawé Indians show the form ha- for the first person, while the form $a$ - is found in the Rio Negro dialect and the form $\int a$ - in dialects of other geographic areas, such as the Solimões River.

Ereré

33)

hasó hamopyryrik se mantéga

ha-só ha-mopiririk se mantéga

1-go 1-fry 1 butter

'I will fry my butter' (HARTT, 1929, p.319).

34)

ixé hakéri yuype

ifé ha-kéri íwápe

1 1-sleep ground-LOC

'I will sleep on the ground' (HARTT, 1929, p.348).

Mawé dialect

35a)

ixé intí haroyar sesé

ifé intí ha-rojár s-esé

1 NEG 1-to.believe $\mathrm{R}^{2}$-in.relation.to

'I do not believe it' (HARTT, 1929, p.362).

Santarém dialect

$35 b)$

xasó xamuí ymyrá yí irúm

fa-só fa-muí ímirá ji irúm

1-GO 1-SPLIT WOOD AX WITH

'I will split the wood with the ax' (HARTT, 1929, p.319).

Monte Alegre dialect

$35 \mathrm{c})$

intí xarekó maá pují uaé

intí Ja-rekó maá pufí waé

NEG 1-have thing bed REL

'I do not have bad things' (HARTT, 1929, p.338). 
Lower Rio Negro dialect

$35 \mathrm{~d})$

Rẹtįịica, iautí curumú xa-pirú indẹ́.

retirîka jautí Kurumú Ja-pirú indé

2.go.away land turtle otherwise 1-step.on 2

'Go out, tortoise, otherwise I step on you!' (MAGALHÃES, 1876, I, p.177).

Stradelli $(1928$, p.357) observes that in some areas of the Rio Negro and the Solimões, the first person prefix had the phonological form a-. This is the form used today in the Upper Rio Negro, as illustrated by the following data:

$\begin{array}{llll}\text { a-maá } & \text { a-purungitá } & \text { a-mundú } & \text { a-mburi } \\ \text { 1-see } & 1 \text {-speak } & \text { 1-send } & 1 \text {-throw } \\ \text { 'I see' } & \text { 'I speak' } & \text { 'I send (it)' } & \text { 'I throw (it) away' (TAYLOR, 1991, p.8). }\end{array}$

37)

a-maã

1 -see

'I see (it)' (TAYLOR, 1991, p.69).

However Tastevin (1923, p.99, emphasis added) has recorded Ja- in the Solimões: "Cet a n'est autre en effet que le pronom personnel "je" qu'ici l'on prononce ša et qui ne fait point partie du verbe

The linguistic data collected by Cabral in 1986 from one of the last speakers of the dialect of the LGA spoken at the Solimões River shows the retention of the form $\int a$ - in the LGA spoken in that region in the $20^{\text {th }}$ century:

$\begin{array}{llllll}\text { ifé } & \text { fa-goxtári } & \text { fa-mãã } & \text { jãa } & \text { kuñãmukú } & \text { r-esé } \\ 1 & \text { 1-tlike } & \text { 1-see } & \text { that } & \text { young.girl } & \mathrm{R}^{1} \text {-in.relation.to }\end{array}$ 'I liked to see that young girl' (CABRAL, 1986).

39)

xa-naséri Sacambú $\quad$-opé
1-be.born Sacambú $\mathrm{R}^{1}$-in
'I was born in Sacambú' (CABRAL, 1986).

The LGA linguistic data "collected" by Magalhães (1876), Stradelli (1928), Hartt (1929), Taylor (1991), and Cabral (1986) offer indications that during the $19^{\text {th }}$ and 
$20^{\text {th }}$ centuries there were at least three distinct forms for the first person prefix accross the dialectal variants of LGA, an evidence that this change cannot be attributed to Jesuit interference.

Yet in Tupinambá, in the indicative mood, when the subject was '1' or '13' and the object ' 2 ' or ' 23 ', the verb did not receive subject prefixes, but object prefixes (oro- '2' or opo- '23', as for example in oro-nupã /('1/13') 2-hit/ 'I/we (excl.) hit you'; opo-nupã /('1/13') 23-hit/ 'I/we (excl.) hit you (plur.)). These combinations of agent and patient were expressed in this way no matter the variety of the indicative mood. However such a pattern is not found in the LGA documents examined here.

The last observations to be made on the Tupinambá indicative I are that, when a first or second person was the patient and a third person was the agent, the subject was not marked on the verb. On the other hand the verb was inflected with the relational prefix $\mathrm{R}^{1}$ and the patient was expressed by an absolutive personal pronoun (sjé r-epják / $1 \mathrm{R}^{1}$-to.see/ 'he saw me'; oré $r$-epják $/ 13 \mathrm{R}^{1}$-to.see/ 'he saw us (excl.)'. The same pattern was found whith a patient of the first person and an agent of the second person. In this particular case, the agent was manifested by a post-verbal ergative pronoun (jepé '2' or pejepé '23') (RODRIGUES, 1998). Of these combinations, only those with the subject in a third or second person were found in the documents of 18th century LGA examined here:

40)

\section{Tupána pemonháng}

$\begin{array}{lll}\text { Tupán-a } & \text { pé } & \emptyset \text {-moján } \\ \text { god-ARG } & \mathbf{2 3} & \mathrm{R}^{2}-\text { make }\end{array}$

god-ARG $23 \quad \mathrm{R}^{2}$-make

'God has made you (pl)' (DOUTRINA..., [16 - ], p.1v).

41)

mbäeráma Tupána jandé monháng?
$\begin{array}{llll}\text { ma'é ráma tupán-a jané } & \emptyset \text {-moján } \\ \text { what for } & \text { god-ARG } 12 & \mathrm{R}^{1} \text {-to.make } \\ \text { 'for what has God made us?' (DOUTRINA..., [16 - ], p.1v). }\end{array}$

An interesting fact to be remarked here is the unsystematic presence of an unstressed final vowel in verbal stems ending in a consonant, a proof that the generalization of this pattern for the verb stems in most dialects of the 18th century LGA had developed gradually. 
a)

mondoçóca

mo-nó-sóka

CAUS-break-break.up

'to break into pieces' (ONOFRE, 1934, p.83).

b)

mocanhémo

mo-kajémo

CAUS-get.lost

'to frighten' (ONOFRE, 1934, p.62).

The other variety of the indicative mood in Tupinambá, the indicative II, was triggered when an adverbial expression preceded the predicate (RODRIGUES, 1953). In this case, the verb did not combine with personal prefixes, but with relational prefixes. The verb stems were also inflected for the modal suffix -i (after consonant) -W (after vowel). In the $17^{\text {th }}$ century LGA, the indicative II was still active (44-45), although there were instances of constructions with the indicative I in situations that originally required the indicative II (46-48): ${ }^{\text {? }}$

43)

$\begin{array}{lll}\text { crúza } & \text { recé } & \text { imojári } \\ \text { cruz- } a & \text { r-esé } & \text { i-mojár-i } \\ \text { cross-ARG } & \mathrm{R}^{1} \text {-in.relation.to } & \mathrm{R}^{2} \text {-nail-IND.II } \\ \text { 'they nailed him on the cross' } & \text { (DOUTRINA..., [16 - ], p.23v). }\end{array}$

44)

pe rapé cycába ybakype cekou

$\begin{array}{lllll}p e ́ & r \text {-apé- } \emptyset & \emptyset \text {-słk-áb- } a & \text { ibák-ipe } & s \text {-ekó-w } \\ 23 & \mathrm{R}^{1} \text {-path-ARG } & \mathrm{R}^{1} \text {-arrive-NOM-ARG } & \text { heaven-LP } & \mathrm{R}^{2} \text {-be-IND.II }\end{array}$

'the end of your path is in the heaven' (DOUTRINA..., [16 - ], p.2).

45)

$\begin{array}{lllll}\text { abá } & \text { recé } & \text { omanó } & \text { cruza } & \text { recé? } \\ \text { aßßá- } \emptyset & r \text {-esé } & \text { o-manõ } & \text { krúz-a } & \text { r-esé } \\ \text { person-ARG } & \mathrm{R}^{1} \text {-in.relation.to } & \text { 3-die } & \text { cross-ARG } & \mathrm{R}^{1} \text {-on } \\ \text { 'for whom did he die on the cross?' (DOUTRINA..., }[16-], \mathrm{p} .24 \mathrm{v}) .\end{array}$

Edelweiss (1969) has called the attention to the absence of the final $i$ corresponding to the modal suffix marking the indicative II. 
46)

mbäétaé çüí omonhang çeté?

$\begin{array}{llll}\text { mba'éta'é } & \emptyset \text {-sui } & \text { o-moján } & \text { s-eté } \\ \text { thing int } & \mathrm{R}^{2} \text {-from } & \text { 3-make } & \mathrm{R}^{2} \text {-body }\end{array}$

'from what did he (God) make his body?' (DOUTRINA..., [16 - ], p.15v).

47)

ndébo oronheángerúr ore poacémbäé oré jacẽõbäébé

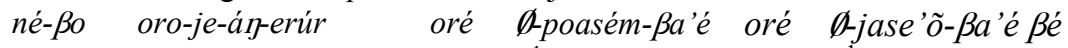

2-DAT 13-REF-soul-bring $13 \quad \mathrm{R}^{1}$-wail-REL $13 \quad \mathrm{R}^{1}$-weep-REL too

'to you we sigh, we who wail, we who cry too'(DOUTRINA..., [16 - ], p.60v).

Besides this oscillation in the use of the indicative II in some varieties of LGA, verbal stems with a final vowel were also inflected either with the allomorph $-i$, which originally combined with verbal stems ending in a consonant, or with the allomorph $-W$, which originally occurred with stems ending in a vowel: "ko sekói ou ko sekóu" "here it is' (VPB, p. 49). This oscillation shows that the phonological conditioning of the allomorphy of the indicative II suffix started to be lost.

In 19th century LGA the indicative II had completely disappeared, except for some expressions such as kuçukúi ãna 'here it is' (MAGALHÃES, 1876, p.165), cuçucui meiú 'here is the food' (MAGALHÃES, 1876, p.146), sucúe, misucui 'here it is' (STRADELLI, 1928, p.186). However this lost was not exclusive of LGA, other Tupí-Guaraní languages have also lost this mood, as it is the case of Wayampí, Zo'é, Emérillon, Urubú-Ka'apór, all belonging to the branch VIII of the family.

\section{The gerundial mood}

In Tupinambá, the condition for a verbal stem to occur in the gerundial mood was the co-reference of its subject with the main clause subject. Transitive verbs combined with relational prefixes and the intransitive ones with the co-referential personal prefixes, and both transitive and intransitive verbs were inflected by the gerundial suffix: -á $\beta O \sim$-ámo (after high vowels, respectively oral and nasal) - $\beta 0$ $\sim$-mo (after low vowels, respectively oral and nasal) and -a (after consonants). The data from $17^{\text {th }}$ century LGA reveal that at that time the gerundial mood was still productive: 
48)

... oapixára pixápixápa icutucutúca inupánupámo jamotarëýma
o-apifár-a
Ø-pifá-pifáp-a
i-kutú-kutúk-a
$\mathrm{R}^{3}$-fellow-ARG
$\mathrm{R}^{1}$-wound-wound- $\quad \mathrm{R}^{2}$-stab-stab-GER
GER

i-nuра̃-nира̃-mo $\quad$ i-amotár-e'tm- $a$

$\mathrm{R}^{2}$-hit-hit-GER $\quad \mathrm{R}^{2}$-love-NEG-GER

'... wounding (in the head) his fellow, stabbing him, beating him, hating him'

(DOUTRINA..., [16 - ], p.71).

49)

cunhã buruá moçangäíba üúbäé opuruá jucápotá

$\begin{array}{lll}\text { kujã-puruá } & \text { m-posáty-a'íb-a } & \text { u-'ú- } \beta a^{\prime} e ́ \\ \text { woman- } & \mathrm{R}^{4-} \text { medicine-bad-ARG } & \text { 3-ingest-NOM } \\ \text { pregnancy } & & \end{array}$

50)

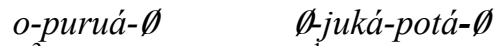
$\mathrm{R}^{3}$-pregnancy-ARG $\mathrm{R}^{1}$-kill-wish-GER
'the woman who drinks a bad potion, wishing to kill her own
pregnancy,

\section{1)}

coipó cunhã apyába recé oicó riré opuruápotárëýma

$\begin{array}{lllll}\begin{array}{l}\text { koipó } \\ \text { or }\end{array} & \text { kujã- } \emptyset & \text { apłá } \beta \text { - } a & r \text {-esé } & \text { o-ikó } \\ \text { woman-ARG } & \text { man-ARG } & \mathrm{R}^{2} \text {-with } & \text { 3-be }\end{array}$

52)

riré o-puruá-potár-e'm-a

after 3CORR-pregnancy-wish-NEG-GER

or the woman not wishing to get pregnant after having been with a man' (DOUTRINA..., [16 - ], p.71).

In the 19th century LGA had already lost the gerundial mood. However, most languages of branch VII and a language of branch V have also lost the gerundial suffix. 


\section{The subjunctive mood}

In Tupinambá a dependent clause occurs in the subjunctive mood when its subject is not co-referential with the subject of the main clause. A verbal stem in the subjunctive mood is inflected with the relational prefixes and with the modal suffix -ame -name (after oral and nasal vowels, respectively) - me (after a labial consonant or $j$ ) and -eme (after other consonants). Even though the subjunctive mood was still used in 17th century LGA (32), the original restriction of noncorreference of subjects between main and subordinate clauses was no more systematically observed (33):

Ore pacárame okaçǘ orecémrame, Tupã ókype Oreikérame, oré kéra janondébé $\begin{array}{lllllll}\text { oré } & \emptyset \text {-páka-rame } & \text { '-ók-a } & \emptyset \text {-su'í } & \text { oré } & \emptyset \text {-sém-rame } & \text { Tupã-ók-ipe } \\ 13 & \text { R1-wake-SUB } & \mathrm{R}^{4} \text {-house-ARG } & \mathrm{R} 1 \text {-de } & 13 & \mathrm{R}^{1} \text {-go.out- } & \text { god-house-LP } \\ & & & & & \text { SUB } & \end{array}$

ore iké-rame oré $\emptyset$-kér-a janoné $\beta$ é 13 go.into-SUB $13 \quad \mathrm{R}^{1}$-sleep-ARG before too

'When we wake, when we leave the house, when we enter the church, also before our sleeping' (DOUTRINA..., [16 - ], p.5).

Xamanopotárame, tamanõ ndé graça pupé, xe mombëúcatúriré fa $\emptyset$-manõ-potá-rame $\mathrm{t}$ a-manõ né $\emptyset$-graça $\emptyset$-pupé $1 \quad \mathrm{R}^{1}$-die-wish-SUB $\quad$ OPT 1 -die $\quad 2 \quad \mathrm{R}^{1}$-grace $\mathrm{R}^{1}$-inside

\section{Se Ø-mome'ú-katú riré}

$1 \quad \mathrm{R}^{2}$-tell-well after

'when I will die, let me die in your grace, after having confessed' (DOUTRINA..., [16 - ], p.77).

There is also evidence from the LGA data recorded in the VPB of a fluctuation of -remeand -rame, as in amôramêand amôremê" "sometimes" (VOCABULÁRIO..., 1951, p.25). A fact of interest here is that some Tupí-Guaraní languages have the form -rame, while others have the form -reme, and still others have -ramo.

By the 19th century, the suffix of the subjunctive mood was reanalysed in LGA as a particle. In some dialects such as those registered by Hartt (1929), Magalhães (1876), and Stradelli (1928), the form ramé had been fixed following not only stems ending in a vowel, but also stems ending in a consonant: 


\section{Dialect of the lower Rio Negro River}

55)

pitúna pucú ramé, coẽma piranga ramé. pitúna pukú ramé ko'éma piránga ramé night long when morning red when 'quando for noite alta, quando for madrugada' (MAGALHÃES, 1876, I, p.170).

\section{Dialect of the Tocantins River}

56)

aitá ocýka ramé

aitá o-sł̣a ramé

they 3-arrive when

'when they arrive' (HARTT, 1929, p.367).

\section{Mundurukú dialect (Tapajós)}

57)

anirá okér ára ramé

anirá o-kér ára ramé

bat 3-sleep day when

'bats sleep during the day' (HARTT, 1929, p.367).

\section{Dialect of the lower Rio Negro River}

58)

Pẹpirári ramé pecanhima curí.

pe-pirári ramé pe-kañáma kurí

2PL-open when 2PL-be.lost FUT

'if you open it, you will be lost' (MAGALHÃES, 1876, I, p.165).

It is important to observe that other Tupí-Guaraní languages also have replaced the original subjunctive suffix by a particle, as it is the case of Tembé, Urubu-Ka'apór, Guajá, among others.

\section{Voice}

The inflectional prefixes je- 'reflexive' and jo- 'reciprocal' continued to occur in the $18^{\text {th }}$ century LGA, although the reciprocal suffix was also used with a reflexive meaning in verbs (59-61) and postpositions (62): 
joausuba

jo-ausú $\beta$-a

REC-love-ARG

'friendship'

(VOCABULÁRIO...,1951, p.20).

60)

Aiocyty

a-jo-kytý

1-REF-rub

'I rub myself' (ONOFRE, 1934, p.196).
61)

Aiocuê

a-jo-ku'é

11-REF-move.the.body

'move, look for'

(ONOFRE, 1934, p.196).

61)

Omomytá cerá erimbäé ojoecé ipý i-pó i-pyá cutucagöera

o-momitá será erima'é o-jo-esé i-pł́ Ø

3-CAUS- doubt once 3-REF- $\mathrm{R}^{1}$-foot-ARG

stay

in.rel.to

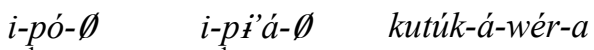

$\mathrm{R}^{1}$-hand-ARG $\mathrm{R}^{1}$-heart- furar-NOM-RET-ARG

ARG

'he kept with himself the marks of the wounds in his feet, hands, and entrails' (DOUTRINA..., [16 - ], p.30).

It is interesting to observe that the reciprocal prefix jo- was used in Tupinambá combined with postpositions with a reflexive meaning (ANCHIETA, 1933, p.1516). Some Tupí-Guaraní languages of the septentrional branch have merged the two forms, as it is the case of Zo'é, Guajá, and Urubú-Ka'apór, a change that also took place in LGA during the XIX century.

\section{Negation}

In Tupinambá, predicates in the indicative mood were negated by means of the particle $n$ (a) preceding the predicate nucleus, which in turn was inflected with the suffix $-i$ (after consoannts) $\sim-j$ (after vowels). In 19th century LGA, the particle nitíw and its reduced variants ití, nti and ti, developed from Tupinambá $n$ i-týb-i / NEG R2-exist-NEG/ 'do not exist'), had been fixed as the general negation device. In fact, nitíw had developed as a particle since the $18^{\text {th }}$ century: 
62)

nitíu acepiac

nitíw a-s-epják

NEG $1-R^{2}$-see

'I don't see it' (DOUTRINA..., [16 - ], p.7).

63)

nitíu abáramo oicobo

nitíw aßá-ramo o-ikó-bo

NEG person-TRANS 3-be.in.movement-GER

'he does not live as a man' (DOUTRINA..., [16 - ], p.53v).

64)

Buopé paa nti osuaixara

Buopépaá nti o-suaixára

buopé QUOT NEG 3-answer

"It's said that Buopé did not answer." (AMORIM, 1987, p.26).

65)

ti kwáw

NEG know

“I don’t know." (STRADELLI, 1928, p.674).

66)

cẹrẹmirẹcó intí okệri putári cẹ irúmo se irúmo

se r-emirekó ĩtí o-kéri-putári

1 REL-wife NEG 3-sleep- wish 1 with

'My wife does not wish to sleep with me.' (MAGALHÃES, 1876, I, p.164).

The $18^{\text {th }}$ century LGA particle nitíuxoéri has a temporal indication of future, probably influenced by the Tupinambá -swér 'instative'. However, the nitíuxoéri particle of LGA was by that time no more segmented as it also happened with the particle nitiu.

67)

Nitíuxoéri opáb

nitíwxoéri o-páb

NEG.FUT 3-end

'it will not end up' (DOUTRINA..., [16 - ], p.32). 
On the other hand, the negation device of dependent predicates in the gerundial and subjunctive moods, which were both realized in Tupinambá by means of the suffix -e'mm, a device also used to negate nouns, was still very productive in the $18^{\text {th }}$ century LGA:

68)

oçopotar bäé c-epiácäym

o-só-potár-ßa'é s-epiák-a'tm

3-ir-querer-NOM $\mathrm{R}^{2-\text { ver-NEG }}$

'one which wishes to go without seeing him' (DOUTRINA..., [16 - ], p.72).

69)

coipó cunhã apyába recé oicó riré opuruápotárëýma

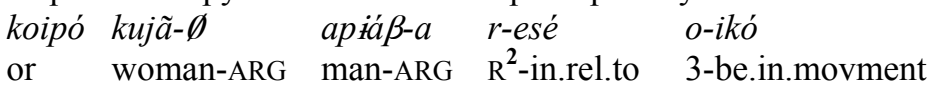

riré o-puruá-potár-e' $m$ - $a$

after 3CORR-pregnancy-wish-NEG-

GER

'or the woman that, after having been with a man, will not get pregnant'

(DOUTRINA..., [16 - ], p.71).

\section{Some comments on the results of the constrastive analysis}

In this study evidence has been presented that the Amazonian Língua Geral (LGA) recorded during the $18^{\text {th }}$ century represents an intermediate stage between the Tupinambá spoken in the North of Brazil during the $17^{\text {th }}$ century and the LGA recorded during the $19^{\text {th }}$ and $20^{\text {th }}$ centuries. This evidence consists of the unsystematic use of inflexional affixes such as the relational prefix $\mathrm{R}^{3}$, the indicative II suffix, the reciprocal and reflexive prefixes, the gerundial suffix, and the translative suffix. The $17^{\text {th }}$ and $18^{\text {th }}$ century LGA documents examined also reveal other changes in progress, such as the use of some original inflectional suffixes realized sometimes as suffixes and sometimes as particles, and the development of new particles such as nitíw and aráma. All of these changes in process in the LGA of the $17^{\text {th }}$ century have consolidated in the $19^{\text {th }}$ century. However, in spite of all the grammatical reductions suffered by LGA between the $17^{\text {th }}$ and $19^{\text {th }}$ centuries, after more than two hundred years of development in a mestizo social context, under various kinds of external interference, it was still reflecting important aspects of the Tupinambá grammar. ${ }^{8}$

As observed in this study, many linguistic changes underwent by LGA since the 18th century are not exclusive of LGA, having also occurred in other languages of the Tupí-Guaraní family. Araweté and 


\section{The LGA and the Jesuits}

It is uncontestable that the Jesuits had an important role in the consolidation and diffusion of LGA during the first 150 years of the Portuguese colonization of Maranhão and Grão Pará. However, the information that can be gathered in the linguistic documents does not provide any basis for the view that the Jesuits were the main agents in the simplification of the Tupinambá language. The information available in the missionary documents offers various indications contrary to this view. It rather suggests that the Jesuit priests were very conservative in the use of the Tupinambá language in their missionary work, naturally more inclined to observe the written form established by their precursors of the $16^{\text {th }}$ and first half ot the $17^{\text {th }}$ century.

\section{Additional remarks}

Finally, the results of the contrastive analysis involving the LGA attested during the $18^{\text {th }}$ century, the Tupinambá registered during the $17^{\text {th }}$ century, and the linguistic data of LGA recorded during the $19^{\text {th }}$ and $20^{\text {th }}$ centuries reveal, among other things, that the differentiation of LGA from the Tupinambá language has occurred processually. They also show that various changes observed in modern varieties of LGA started developing during the first hundred years of its history, when the language started to be spoken outside the original Tupinambá social contexts. The results of the present study match Thomason and Kaufman observation that

[...] a claim of genetic relationship entails systematic correspondences in all parts of the languages, because that is what result from normal transmission: what is transmitted is an entire language - that is, a complex set of interrelated lexical, phonological morphosyntactic, and semantic structure. (THOMASON; KAUFMAN, 1988, p.11).

CABRAL, A. S. A. C.; RODRIGUES, A. D. Uma contribuição à história linguística da língua geral amazônica.

Zo'é are good examples of languages that, far from having been influenced by the Portuguese language, underwent changes similar to those observed in LGA. Araweté has lost the Tupí-Guaraní modal suffixes, the negation suffix of predicates, the accusative personal prefix ' 2 ', the argumentive case, as well as it has developed a first person plural inclusive pronoun which replaced the original Tupí-Guaraní form and has developed a new negative particle (VIEIRA; LEITE, 1998). Zo'é also has lost the gerund and indicative II modal suffixes; it has developed two negative particles and lost some personal prefixes and pronouns (CABRAL, 2001). Urubú-Ka'apór has lost the negation suffix of predicates as well as the contrast between inclusive and exclusive first person, and has developed an associative particle (CORRÊA DA SILVA, 1997). However, all of these languages keep regular correspondences with the other languages of the family, as does LGA. 
- RESUMO: Este artigo mostra que as mudanças ocorridas na Língua Geral Amazônica durante 300 anos, embora esta língua tenha sido exposta a interferências externas do Português e de inúmeras línguas indígenas, foram graduais, sem que tenha havido interrupção em sua transmissão. Isso demonstra que sua origem foi genética, de acordo com os princípios que subjazem ao Método Histórico comparativo e de acordo com o modelo teórico proposto por Thomason and Kaufman (1988). Esta abordagem reúne evidências contra as visões de que a Língua Geral Geral Amazônica é uma língua crioula ou uma língua desenvolvida no século XVII pelos missionários jesuítas. Dessa forma, este artigo contribui para a visão de que a Língua Geral Amazônica é uma versão do Tupinambá, que se desenvolveu fora das aldeias Tupinambás, mas mantendo suas relações genéticas com o subramo III da família linguística Tupí-Guaraní, junto com o Tupinambá, com o Tupí Antigo e com a Língua Geral Paulista, como proposto por Rodrigues (1985) na sua classificação interna desta família linguística.

- PALAVRAS-CHAVE: Língua Geral Amazônica. Mudanças históricas. Transmissão normal. Interferências externas. Família Tupí-Guaraní.

\section{REFERÊNCIAS}

AMORIM, A. B. de. Lendas em nheengatú e em português. Manaus: Fundo Editorial-ACA, 1987.

ANCHIETA, J. de. Arte de grammatical da lingua mais usada na costa do Brasil. Rio de Janeiro: Biblioteca Nacional, 1933. Edição facsimilar.

BETTENDORF, J. P. Padre. Compendio da doutrina christãa na língua portuguez, \& brasílica. Lisboa: Miguel Deslandes, 1687.

CADERNO da língua ou vocabulário português-tupí. Atribuído a Frei João de Arronches (1739), com notas e comentários de Plínio Ayrosa. Revista do Museu Paulista, São Paulo, v.21, 1937.

CABRAL, A. S. A. C. Prefixos relacionais na família Tupí-Guaraní. Boletim da ABRALIN, Fortaleza, n.25, 2001. p.213-262.

Notes from field works. Brasília, 1986. Manuscrito.

CORRÊA DA SILVA, B. C. Urubú-Ka'apór, da gramática à história: a trajetória de um povo. 1997. 160f. Dissertação (Mestrado em Linguística) - Instituto de Letras, Universidade de Brasília, Brasília, 1997.

DOUTRINA Christão em Lingoa Geral dos Indios do Estado do Brasil e Maranhão, composta pelo P. João Philippe Bettendorff, traduzida em Lingoa Geral irregular e vulgar uzada nestes tempos. Coimbra, [16--].

EDELWEISS, F. G. Estudos tupis e tupi-guaranis. Rio de Janeiro: Livraria Brasiliana, 1969.

FIGUEIRA, L. Arte de grammatica da lingua brasilica 2.ed. Leipzig:Teubner, 1878. Fac-símile da edição de 1687. 
HARTT, C. F. Notas sobre a língua geral ou Tupi moderno do Amazonas. Comentário de Rodolfo García. Anais da Biblioteca Nacional, Rio de Janeiro, n.51, p.305-390, 1929.

MAGALHÃES, J.V. C. de. O Selvagem:I. Curso de Língua Geral segundo Ollendorf, comprehendendo o texto original de lendas Tupis; II. Origens, costumes, região selvagem, methodo a empregar para amensal-os por intermédio das colônias militares e do interprete militar. Rio de Janeiro: Typographia da Reforma, 1876.

ONOFRE, Frei. Dicionário português-brasiliano e brasiliano-português: reimpressão integral da edição de 1795, seguida da $2^{a}$ parte até hoje inédita, ordenada e prefaciada por Plínio M. da Silva Ayrosa. Revista do Museu Paulista, São Paulo, v.18, 1934.

RODRIGUES, A. D. As línguas gerais sul-americanas. Papia, Brasília, v.4, n.2, p.618, 1996.

The grammatical structure of classical Tupí. Leiden, 1994. Material elaborado para cursos da Universidade de Leiden. Não paginado.

Relações internas na família linguística Tupí-Guaraní. Revista de Antropologia, São Paulo, n.27/28, p.33-53, 1985.

. Estrutura do Tupinambá. Campinas, 1981. Manuscrito.

. Morfologia do verbo tupi. Letras, Curitiba, v.1, p.121-152, 1953.

. Análise morfológica de um texto tupi. Logos, Curitiba, v.15, p.56-77, 1952.

STRADELLI, E. Vocabularios da lingua geral portugues-nheengatú e nheengatúportugues, precedidos de um esboço de Grammatica nheênga-umbuê-sáua mir̂̂ e seguidos de contos em língua geral nheêngatú poranduua. Revista do Instituto Histórico e Geographico Brasileiro, Rio de Janeiro, t. 101, v.158, p.9-768, 1928.

TASTEVIN, C. Grammatica da língua Tupy, vocabulário Tupy-Portugues, Nomes de plantas e animais em língua Tupy. Revista do Museu Paulista, São Paulo, n.13, p.537-763, 1923.

TAYLOR, G. (Coord.). Caderno de leitura nheengatu 1: vamos escrever a nossa língua. Manaus: Universidade do Amazonas, 1991.

THOMASON, S. G.; KAUFMAN, T. Language contact, creolisation, and genetic linguistics. Los Angeles: University of California Press, 1988.

VIEIRA, M. M. D.; LEITE, Y. F. Observações preliminares sobre a língua Araweté. Moara: revista dos Cursos de Pós-Graduação em Letras da Universidade Federal do Pará, Belém, n.9, p.7-31, 1998. 
VOCABULÁRIO Português-Brasílico: manuscrito do século XVIII transcrito e ordenado por Plínio Ayrosa. Boletim da Faculdade de Filosofia, Ciências e Letras da Universidade de São Paulo, São Paulo: etnografia e tupi-guarani, n.21, 1951.

\section{BIBLIOGRAFIA CONSULTADA}

CABRAL, A. S. A. C. Observações sobre a história social da Língua Geral Amazônica. In: SIMÕES, M. S. (Org.). Memória e Comunidade, Belém: Gráfica Universitária, Universidade Federal do Pará, 2000. p.103-129.

Algumas evidências linguísticas de parentesco genético do Jo'é com as línguas Tupí-Guaraní. Moara: revista dos cursos de pós-graduação em Letras da UFPA, Belém, n.4, p.47-76, 1996.

RODRIGUES, A. D. Caso em Tupí-Guaraní, particularmente em Tupinambá. In: CONGRESSO DA ANPOL, 13., 2000, Niterói. Anais... Niterói:Associação Nacional de Pós-Graduação e Pesquisa em Letras e Linguística, 2000. 1 CD-ROM.

. Alguns casos de regramaticalização em línguas da família Tupí-Guaraní. In: SEMINÁRIO PERMANENTE DE LÍNGUAS INDÍGENAS, 20., 1998, Belém. Anais... Belém: Ed. da UFPA, Belém, 1998.

Recebido em março de 2011.

Aprovado em julho de 2011. 